\title{
Curriculum Politics in the Changing Fortunes of Nigerian Social Studies
}

\author{
Biodun Ogunyemi \\ Dept. of Curriculum Studies and Instructional Technology \\ Faculty of Education, Olabisi Onabanjo University \\ Ago-Iwoye, Ogun State, Nigeria \\ Tel: 234-8055-475-878_E-mail: ogunyemi_biodun@yahoo.com
}

\begin{abstract}
The paper reviews the impact of political decisions on the development of school social studies in Nigeria. From its shaky start in the 1960s, the school subject was eventually adopted for all primary as well as junior and senior secondary schools under the national policy on education by the 1990s but later restricted to the junior secondary in 2004. Through a conceptual analysis of its evolution, this paper argues that the initial intellectual and altruistic undercurrents that informed the adoption of an integrated social studies seemed to have been overridden by 'curriculum politics'. Illustrations are drawn from the changing fortunes of the school subject and the current threats facing it within the school system. It is suggested, among others, that educational policy makers should keep to the raison d'etre for the initial introduction of Social Studies as Nigeria strives to address the crisis of nation building and national development.
\end{abstract}

Keywords: Curriculum, Politics, Educational Policy, Nigerian Social Studies 
If there is one proposition about curriculum politics that is clear, it is that school curriculum becomes an issue in communities and societies that are undergoing significant social change ...curriculum policy making...generally is characterized by the ...mundane strategy of disjointed incrementalism.

--- William Boyd (in Sachs, 2001).

\section{Introduction}

Politics permeates all human activities, including education. In Africa and many other post-colonial societies, research evidence suggest that ongoing efforts at deploying education for nation building and national development are mostly driven by political considerations (Woolman, 2001; Musa, 2005; Ho \& Alviar-Martin, 2010). Weber (1971) explains politics in relation to power and strive to influence the distribution of power among nation-states as well as among groups within a state. According to Musgrave (1979:272), 'polity' refers to "that group of mechanisms which a society develops to deal with the almost universal set of social problems of deciding what is the common good and of ensuring that action follows upon the decision". The polity therefore provides the platform for politics or political activities.

Three essential elements in the understanding of political relations are power/influence, authority and resources. Political actors strive to determine and influence activities and events around them. They do this either by appealing to the sensibilities of other people to lead them, as in democracy, or by hijacking the machinery of governance for authoritarian rule as in the case of the military rulers who, until the 1990s, dominated the political landscape of Nigeria and Africa. Whether by peaceful or violent means, those who control the machineries of the state or polity assume authority to allocate resources and take decisions that shape the lives of others under their rule. Through policy formulations and legislative procedures, they determine what happens virtually in all areas of the people's life including the substance of their education or curriculum. Curriculum theorists have therefore consistently made direct and indirect references to curriculum politics (Tyler, 1949; Wheeler, 1967; Doll, 1978; Ogunyemi, 2009).

The concern of this paper is how curriculum politics constitutes a setback for the development of social studies education in Nigeria. What is curriculum politics? To what extent has curriculum politics contributed to the changing fortunes of the Nigerian school social studies? How best can the 'dark spot' created by politics be removed? Finding answers to these principal questions constitute the primary focus of this paper.

\section{Curriculum Politics as the 'Dark Spot' in Nigerian Education}

Curriculum conception, formulation, review and implementation are all human activities that take place within a polity. The ultimate goal of curriculum is the production of the type of citizens desired by the society (Westheimer \& Kahne, 2004; Kahne \& Middaugh, 2008) and this makes the curriculum process vulnerable to manipulation by political actors. As succinctly summed by Doll (1978:105), 
[T] he curriculum leader must realize that he (or she) is deep in politics. His (Hers) is not the politics of the ward-heeling variety but of strategic planning that requires balancing of pressures and cooperative making of policy. Educators should probably stop talking about the “administrator's community relations” and talk instead about his (or her) ability as a competent and constructive politician. The curriculum leader is inevitably concerned with pressure groups and with allocations of public funds. These two areas of his (or her) responsibility alone thrust him (her) into the realm of politics.

Doll may as well be saying that curriculum builders and leaders are, consciously or otherwise, entangled in political relations and the earlier they come to terms with this realization the better for their activities as educators. Central to these relations is 'curriculum lobby' as political actors engage themselves in subtle supremacy contest. This is particularly so in post-colonial African countries, including Nigeria, where concrete structures for curriculum decisions and development are not fully established (Ivowi, 1998). Consequently, there is a confused state of affairs that tend to reverse gains in strategic curriculum areas rather than advancing the course of transforming their citizens and societies.

William Boyd, as referenced in the preface to this article, makes the point that curriculum politics is a prominent feature of social and policy dynamics in societies undergoing rapid transformation such as Nigeria. As Boyd (cited in Sachs, 2001) argues, this involves "mundane strategy of disjointed incrementalism". Sachs (2001) identifies three major implications of such development for curriculum change and control which are relevant to the Nigerian environment. First, curriculum policy is a site of struggle; professionals versus bureaucratic agendas, political interests versus educational processes and outcomes, social versus political needs, and so on. The second political issue is that of the content and processes of curriculum and curriculum development which are products of the first. Thirdly, curriculum documents are open to multiple readings and despite attempts by bureaucracies to impose a preferred reading on the curriculum text, teachers, in the privacy of their own classrooms interpret and implement these documents on the basis of their own experience, discipline base, beliefs and philosophy of teaching and education; thus making a nonsense of the official attempt to control the meaning. These dimensions highlighted by Sachs are critical to the understanding of curriculum politics in Nigeria. They indeed present a framework for understanding the "dark spots” in Nigerian education.

Curriculum politics is an inescapable fact of education. Adedipe (1985) remarks that those who wish to make education non-political are either failing to understand that the purposes and procedures of education reflect what people want, or they are trying, perhaps unconsciously, to restrict the rights of fellow citizens to participate in decisions of deep and abiding importance to them. Nevertheless, politics could do more harm than good to the content and process of education if not well handled. Unless national interests were placed above individual or sectional interests, the ultimate goal of promoting the greatest good for the greatest number, which must necessarily underline every enduring political decisions, would be lost. 
In the unwavering rejection of the inherited colonial education in the 1950s and 1960s, curriculum politics was on display with copious reference to patriotic sentiments among Nigerian leaders of that era (Woolman, 2001). The expressed desire to build a strong, united and dynamic nation informed the early experimental projects like the Basic Science (1962) and Social Studies (1963). An assessment of these projects revealed that they gave directions for the initial change needed for meaningful education in Nigeria (Ivowi 1984). Subsequent developments however suggest that the patriotic fervor of the 1960s and 1970s soon whittled away especially with the dominant presence of military autocrats on the political landscape until May 29, 1999.

Available evidence points to the Nigerian curriculum development process as "a site of struggle” in post-independence Nigeria. In particular, the 1980s and 1990s witnessed the introduction of several policies which many Nigerians regarded as too political (Awokoya, 1981; Ogunyemi, 1998). For instance, government proposed to equalize educational opportunities through such measures like education of the gifted, education of women, and nomadic education. However, the desperation with which these policies were introduced and the passion with which they were equally resisted in some parts of the country pointed to how much the conscious segments of the Nigerian public were prepared to sacrifice national interests for personal or sectional gains. Here, as Sach would argue, we saw an extensive manifestation of conflicting interests: "professionals versus bureaucratic agendas, political interests versus educational processes and outcomes, social versus political needs, and so on" (Sach, 2001).

The formulation of an educational policy in 1977 was seen by many as a step in the right direction. The policy was tailored towards reconstructing the curriculum "to reflect indigenous traditions, social change and empowerment (which) was advocated by African critical theorists from the late $19^{\text {th }}$ century" (Woolman, 2001: 27). However, its implementation soon became a major source of worry as education turned a theatre of ideological combat. The case in point was the "quality versus quantity" education debate among political party leaders of Nigeria's second republic (1979-83). Little was it realized that quantitative and qualitative education must not remain an idle dream, a vain election promise to collect votes and establish a conspiracy to rule as was evident in the ensuing activities of the politicians (Awokoya, 1981). The debate indeed triggered a chain of events which adversely affected the implementation of the educational policy even long after the collapse of the second republic in December 1983. An observer of trends in curriculum development of this era had this to say:

Apart from a few cases, proper planning to allow a step by step development of curriculum projects has not taken place. Trial testing of materials has occurred only in projects developed by one organization. Even with the programmers for the JSS where adequate notice was given for the introduction of the new system, pilot testing of materials before their installation into the entire school system has not occurred (Ivowi, 1984:354). 
It has equally been shown that majority of Nigerian primary and secondary school teachers are largely curriculum illiterates (Kosemani, 1984; Mkpa, 2005). This, in itself, is capable of undermining whatever curriculum innovation efforts are being initiated in the country; thus reinforcing the third leg of Sach's curriculum politics tripod. A foundation for this resides in the overwhelming presence of untrained and under-qualified teachers who are ill-prepared "to function as curriculum implementers, evaluators and innovators” (Kosemani, 1984). One of the worst hit school subjects in this regard is Social Studies.

\section{The changing fortunes of the Nigerian school social studies}

The finest moment for Social Studies curriculum development efforts in Nigeria could be put at the period between 1969 and 1977. This period marked the era of rapid curriculum innovations starting with the first national curriculum conference and culminating in the emergence of the National Policy on Education (NPE) in 1977. Several recommendations at the National Curriculum Conference held from September 8 to 12, 1969, pointed in the direction of Integrated Social Studies and made it an irresistible core component of the educational policy document that eventually emerged. Specifically, Decision Area VIII of the Conference Report, dedicated to "Education for Living", contains landmark recommendations (47-50) which underscore the import of Social Studies for the production of new Nigerians and the making of a new nation (Adaralegbe, 1972).

The formulation of the educational policy gave impetus to the development of Social Studies education which began on an experimental basis at the Aiyetoro comprehensive high school in 1963. The Aiyetoro experiment had been facilitated by the defunct Western Regional Government in collaboration with the Ford Foundation and the University of Washington, USA. Highlights of this steady growth at the primary education level included the development of national curriculum guidelines for Social Studies in 1971, 1983 and 1988. At the secondary level, the experiment in Aiyetoro yielded objectives and themes that transformed into the Nigerian Social Studies Programme (NSSP) in the 1970s and 1980s. The NSSP was further expanded with the collaboration of the Nigerian Educational Research Council (NERC, now Nigerian Educational Research and Development Council) with the Comparative Education Study and Adaptation Centre (CESAC) based at the University of Lagos to develop the Nigerian Secondary Schools Social Studies Project (NSSSP). Through these collaborative efforts, relevant books and illustrational materials were produced for its teaching at the first three years (JSS I-III) of the two-tier (junior and senior) secondary education program introduced by the NPE as from 1982. The formation of the Social Studies Association of Nigeria (SOSAN) in 1971 gave additional boost to the rising profile of the subject in the country.

There have been five versions of the NPE to-date: 1977, 1981, 1998, 2004 and 2007editions to date. Social Studies enjoyed highest-level recognition in the first three editions as it was made compulsory at the Junior Secondary School (JSS) and a core-elective at the Senior Secondary School (SSS) level. The hope of getting the subject its strongest foot was further brightened when, in addition to the JSS National Curriculum for Social Studies, an SSS program was developed by the Federal Government through the Nigerian Educational 
Research and Development Council (NERDC) in 1985. The SSS Social Studies was designed to take off that year and this would have made it examinable by the West African Examination Council (WAEC) as obtained in Ghana. However, the SSS curriculum remained a lame-duck until it was finally blanked out by the Nigerian government through the 2004 and 2007 editions of the NPE. In this latest edition of the policy document, Social Studies has lost its place within the SSS curriculum and replaced by a new program of Civic Education. The new addition, Civic Education, has also been introduced to co-exist with social studies at the primary and junior secondary school levels (NERDC, 2007).

A wave of confusion thus seems to be emerging in Social Studies curriculum development process in Nigeria. Much of this confusion bother on politics, and it is clearly palpable at federal government level which is the highest level of governance in the country. According to Obebe (Obebe, 2007: 2),

In the last three top meetings where Social Studies was put on the Block, there was one where we were to disarticulate social studies themes for Civic Education/Citizenship Education. In another we were to define Civic Education/Citizenship Education, Voter Education and Social Studies. Whichever got the greatest appeal would be selected by the organizers. Even at one of the workshops we were confronted with the stack reality that one of this must go: (i) Social Studies, (ii) Civic Education, (and) (iii) Citizenship Education. From the discussions leading to the point where the statement was put to us that one of the three must go, one could seen the organizers' preference for CIVIC EDUCATION as we were told 'It was order from the above that CIVIC EDUCATION must replace SOCIAL STUDIES'. Nobody has done much for Citizenship Education as we were made to understand.

This looks like a great setback on the platform of curriculum politics for a nation that, as from the 1960s, adopted an integrated approach to social studies education. Obebe's reports, given at the $8^{\text {th }}$ National Conference of the Social Studies Association of Nigeria (SOSAN) in 2007, clearly attest to the magnitude of the threat facing Nigerian Social Studies education. For it is unimaginable that the same Federal Government that invested so much in the initial training of experts, curricular development and book projects at various educational levels could turn around to sponsor an official decimation of the school subject. Several questions were expectedly raised by critical observers at the 2007 SOSAN conference. Much of the questions revolve around policy inconsistencies with respect to the adoption of the integrated approach to Social Studies; the relationship of Social Studies to older school subjects (Geography, Economics, History, Government, etc.); and the need to borrow from best practices in other African countries sharing similar antecedents with Nigeria.

The idea of dropping Social Studies at the senior secondary (SSS) level was a political decision. The over-politicization of the school subject has, expectedly, been condemned by members of the Social Studies Association of Nigeria (SOSAN) whose early influence on curriculum development process in the field has since waned. Many commentators on Nigerian Social Studies (Akinbote 1995; Obebe \& Olatunde 2005; Iyela, 2005; Ogunyemi, 2007) agree that the unfolding scenario marks an anti-climax in the steady development of 
the school subject. Without doubt, the cancellation of social studies from the SSS curriculum and ongoing efforts to whittle down its presence at the junior secondary is bound to have ripple effects on the attainment of the goals of Nigerian education in general (Ogunyemi, 1998, 2007). As noted elsewhere,

The sense of inferiority reported by pre-service social studies teachers ... may have been confounded with the removal of the subject from the secondary school curriculum where it was (nominally) listed ... Government seems to have bowed to pressures from the separate subject specialists, particularly historians, and this is bound to reverse the gains made in the development of qualitative social studies teacher education way back from the 1960s (Ogunyemi, 2007: 14).

Beside teacher-related problems, several existing conceptual and implementation problems (Ogunyemi, 1998, 1999, 2006; Iyela, 2005) are likely to take a turn for the worse. These include definitional problem, resistance by separate subject specialists and non-specialist school administrators; and paucity of relevant books and instructional materials. Indeed, this seeming reversal of the fortunes of the Social Studies in the NPE has no precedent in any other part of Africa (Shiundu \& Mohammed, n.d). If anything, the subject seems to be gaining increasing ascendancy within the school curricula elsewhere in the continent. In Ghana, there is a Senior Secondary School Social Studies program that is being examined by the West African Examination Council. A similar trend is emerging in Sierra Leone. Given the striking similarities of the Ghanaian and Nigerian socio-cultural and political experiences, it looks foolhardy to undermine the advancement of the Social Studies project in Nigeria.

\section{Back to basics?}

The surest way to guarantee its philosophical and historical sustainability is for government to return to the spirit and letters of the Nigerian Social Studies Project (NSSP); as this was knitted to the country's aspirations for nation building and national development. Like every other emerging nation, Nigeria's objectives as a country provide the pivot for its activities in the realms of curriculum development and education in general. These objectives for building the desired nation are five:

(a) free and democratic society;

(b) a just and egalitarian society;

(c) a united, strong and self-reliant nation;

(d) a great and dynamic economy; and

(e) a land full of bright opportunities for all citizens (Federal Republic of Nigeria, 2004).

The core message in all this is that Nigeria needs a new crop of citizens who can effectively address its developmental challenges as a post-colonial state. The then Chief Federal Adviser on Education, Dr. S. J. Cookey, in his Keynote Address to the first National Curriculum 
Conference, acknowledged the place of Social Studies and Citizenship Education in this project by observing that:

I agree with those who say that citizens are made, not born, and I agree with those who believe that citizenship can be taught. If the understanding and practice of citizenship among Nigerians is a true measure of the Nigerian educational system, then that system has failed woefully, for we have tended to lead each one his (her) own individual life, and each family or group for itself. We have not yet begun to think of Nigeria as one and of each one of us as intrinsically part of the Nigerian society. This has been the tragedy of our past, and now is the opportunity to remedy the shortcomings of the past (Cookey, 1972: xxxi).

That was way back in 1969. What Cookey said more than four decades ago is, undeniably, still relevant to today's Nigeria. Fafunwa (2010) recently alluded to this individualistic spirit among Nigerians fifty years after political independence from Britain. In his words, "Left unabated at this rate, every Nigerian would have his own state, plus his own university in his backyard" (Fafunwa, 2010: 80). To a large extent, this attests to the seeming failure of Social Studies to contribute meaningfully to the Nigerian dream and much of this could be attributed to curriculum politics.

The goal of producing honest, committed, knowledgeable, patriotic and diligent citizens which was the ground for introducing an innovative and value-oriented Social Studies in the 1960s and 1970s has remained a forlorn hope, if not a wishful thinking. The bright spots in the development of Social Studies education in Nigeria seem to have been blotted by contemporary revisionism and reductionism driven more by curriculum politics than patriotic vision. The imperatives for civic education, voter education and such other variant elements of integrated Social Studies are undeniable in the Nigerian environment reputed for electoral violence and prolonged military dictatorship. However, these emergent curriculum areas need not threaten the survival of Social Studies on the school time table; rather, they should serve to enrich the content and pedagogies of the subject in Nigerian schools where the intents are devoid of a 'curriculum warfare'.

Like in many other parts of the world, Nigerian separate subject specialists, particularly in History and Geography, never wished that Social Studies should survive (Wronski 1981; Akinbote, 1995). No one can deny the relevance of the knowledge of the History or Geography of a nation to its growth and development and the presence of these subjects on the SSS curriculum is desirable. The problem however is the inexplicable circumstances that led to the extermination of Social Studies. One would have thought, for instance, that its core-elective status at that level be retained with the proviso that "Students offering Social Studies cannot offer any of Geography, History and Literature-in-English” as stipulated in the third edition of the NPE (Federal Republic of Nigeria 1998: 22). In that case, Nigeria would have been doing a similar thing with Ghana where the senior secondary curriculum has ample provision for elements of the country's history and geography to make up for the gap that might be created where a student opted for Social Studies in lieu of these older school subjects. Apparently, this was the point from where the Nigerian social studies curriculum 
development all began. It is strongly suggested that the country returns to the drawing board in order to seriously address the dark spot in the steady development of the school subject created largely by "curriculum contractors" (Ogunyemi, 2007). Such individuals are hardly able to place State interests above self interests in a context that requires the development of pluralistic or multicultural citizenship values for sustainable democracy (Ho \& Alviar-Martin, 2010). Until their activities is put under check, the benefits of value and knowledge transformation inherent in Social Studies as citizenship education in a globalizing world (Kerr, 1999; Heafner, 2008) may elude the Nigeria.

\section{Conclusion}

The experience of curriculum marginalization is not peculiar to the Nigerian Social Studies program. In the United States, Leming and Ellington (2003:i) have observed that "The only possible interpretation of the state of social studies education at the turn of the 21st century is that the field is moribund." Adler and Sim (2005: 1) report that, despite the importance officially attributed to Social Studies in the national curricula, "it remains a low status subject, with little time allowed for the development of conceptual understanding and important skills" in Singapore. In South Korea, Jho (2006: 21) states that "the practice of social studies education aimed at promoting civic competence is not clear". And In Finland, Social Studies is regarded as "somewhat an incoherent and ambiguous subject" (Virta, 2005). The most interesting thing about these reports of the 'decline' of Social Studies is that they have triggered genuine efforts aimed at advancing the course of social studies education.. This seems not to be the case with Nigeria.

The changing fortunes of Social Studies education in Nigeria was not unconnected with curriculum politics. This development has the potential of worsening the conceptual and implementation problems with which the subject has had to contend since it was introduced in the country. As a way of reversing the unhealthy trend, this review suggests that government must go "back to the basics" of the Nigerian Secondary Schools Social Studies Project (NSSSP) which established the philosophical basis for its teaching and learning at that level. It is only then the education in Social Studies can be in tune with the country's national objectives.

\section{References}

Adaralegbe, A. (Ed.). (1972). A philosophy for Nigerian education. Ibadan: Heinemann Educational Books, Nigeria, Ltd.

Adedipe, V. O. (1985). Education and politics. In O. Y. Oyeneye \& M. O. Shoremi (Eds.), Sociology of education: A book of readings (pp. 71-87). Ibadan: Ogunsanya Press Publishers \& Bookstores Ltd.

Adler, S. A., \& Sim, J. B. (2005). Social Studies in Singapore: Contradiction and control. Paper to be presented at the Redesigning Pedagogy: Research, Policy, Practice Conference, 30 May 11 June.2005, Centre for Research in Pedagogy and Practice, National Institute of Education, Singapore 
Akinbote, O. (1995). A note on citizenship education in Nigeria: Retrospect and prospect. Canadian Social Studies, 30(1), 30-32, Fall.

Awokoya, S. O. (1981). Futuristic perspectives of the quantity and quality of Nigerian education. Education and Development. 1(2), July, 80-89.

Cookey, S. J. (1972). Keynote address. In A. Adaralegbe (Ed.), A philosophy for Nigerian education. Ibadan: Heinemann Education Books (Nig.) Ltd. xxi-xxxii.

Doll, R. C. (1978). Curriculum improvement: Decision making and process (4 ${ }^{\text {th }}$ Edition). Boston: Allyn and Bacon, Inc.

Fafunwa, A. B. (2010). No more states and universities. The Guardian (Lagos), August 31, 2010.

Federal Republic of Nigeria. (1977). National Policy on Education. Lagos: NERC Press.

Federal Republic of Nigeria. (1998). National Policy on Education (3 ${ }^{\text {rd }}$ Edition). Lagos: NERDC Press.

Federal Republic of Nigeria. (2004). National Policy on Education (4 ${ }^{\text {th }}$ Edition). Lagos: NERDC Press.

Heafner, T. L. (2008). What does it mean to be a citizen?: Defining social studies in the age of marginalization and globalization. Journal of Curriculum and Instruction, 2(1): January. (Online). Available: www://http.joci.ecu.edu (December 20, 2009).

Ho, L., \& Alviar-Martin, T. (2010). Between self and state: Singapore social studies teachers' perspectives of diversity. Journal of International Social Studies, 1(1), 20-33, Fall.

Ivowi, U. M. O. (1984). Curriculum studies in Nigeria. In PAI Obanya (Ed.), Curriculum: In theory and in practice. Ibadan: Faculty of Education, University of Ibadan, pp. 341-357.

Ivowi, U. M. O. (1998). A new structure for Nigerian school curricula. Studies in Curriculum, 2: $1-11$.

Iyela, A. (2005). Overcoming the constraints to social studies innovation in Nigeria. In S. O. Oriafo, G. D. Edozie \& D. N. Ezeh (Eds.), Curriculum issues in contemporary education. Benin-City: Da-Sylva Influence, pp. 140-146.

Jho, D. (2006). The making of social studies education in Korea: Implications for citizenship education. Citizenship Teaching and Learning, 2(2): 21-36, December.

Kahne, J., \& Middaugh, E. (2008). High quality civic education: What is it and who gets it? Social Education, 72(1), 34-39

Kerr, D. (1999) Citizenship Education: an international comparison. London, QCA/NFER.

Kosemani, J. M. (1984). Teachers: The missing link in the Nigerian curriculum process. In PAI Obanya (Ed.), Curriculum: In theory and in practice. Ibadan: Faculty of Education, University of Ibadan, pp. 341-357. 
Leming, J. S., \& Ellington, L. (2003). Passion without Progress: What's wrong with social studies education? In Leming, J., Ellington, L., \& Porter-Magee, K. (Eds.), Where did social studies go wrong? USA: The Thomas B. Fordham Foundation, pp. i-vi.

Mkpa, M. A. (2005). Challenges of implementing the school curriculum in Nigeria. Nigerian Journal of Curriculum Studies, 12(1): 9-17.

Musa, J. M. (2005). The implementation of progressivism in Nigerian education: An assessement. Unpublished Ph. D thesis, University of Jos, Nigeria.

Musgrave, P. W. (1979). The sociology of education ( $3^{\text {rd }}$ Edition). London: Methuen \& Co. Ltd.

NERDC. (2007). 9-Year Basic Education Curriculum - social studies for upper basic education (JS 1-3). Lagos, Nigerian Educational Research and Development Council Publishers.

Obebe, B. J. (2007). Social studies as a catalyst in innovation and change.Text of a Lead Paper presented at the $8^{\text {th }}$ Annual National Conference of Social Studies Association of Nigeria (SOSAN) held at the Kwara State College of Education, Ilorin, $21^{\text {st }}$ November, 2007.

Obebe, B. J., \& Olatunde, F. A. (2005). Social studies curriculum in Nigerian schools: Nature, scope and prospects. In S. O. Oriaifo, G. D. Edozie \& D. N. Ezeh (Eds.), Curriculum issues in contemporary education. Benin-City: Da-Sylva Influence, pp. 130-139.

Ogunyemi B. (2007). Some theoretical considerations for quality assurance in initial social studies teacher education”. Paper presented at the $20^{\text {th }}$ Conference of the Curriculum Organization of Nigeria held at the Abia State University, Uturu, between $20^{\text {th }}$ and $22^{\text {nd }}$ September, 2007.

Ogunyemi, B. (1998). Social studies curriculum under the 6-3-3-4 system: Conceptual and implementation issues revisited. Nigerian Journal of Curriculum Studies, Special, 88-95.

Ogunyemi, B. (1999). Functionality of social studies: An analysis of current conceptions among undergraduate teacher-trainees. Nigerian Journal of Curriculum Studies, 6(1): 56-63.

Ogunyemi, B. (2006). Curriculum implications of the Decade of Education for Sustainable Development for primary school social studies. Nigerian Journal of Curriculum Studies, 13(1), 175-184.

Ogunyemi, B. (2009). Some key concepts for understanding curriculum. In Curriculum Organisation of Nigeria, Curriculum Theory and Practice. Abuja: Topboddy Nigeria Publishers, pp. 1-20.

Sachs, J. (2001). Curriculum control: The cost to teacher professionalism. Paper presented at AARE Conference Fremantle, 3-7 December, 2001.

Shiundu, J. O., \& Mohammed, A. (n.d). (2005). Issues in social studies teacher education in Africa”. [Online] Available: http://www.ncsu/aern/socstd.hotml, retrieved 13th June. 


\section{IIMacrothink}

International Journal of Education

ISSN 1948-5476

2010, Vol. 2, No. 2: E10

Tyler, R. W. (1949). Basic Principles of Curriculum and Instruction. Chicago: University of Chicago Press.

Udoukpong, B. E., Emah, I. E., \& Okon, C. E. (2006). Social studies as a vehicle for citizenship education in Nigerian primary schools in the $21^{\text {st }}$ century. Nigerian Journal of Curriculum Studies, 13(2), 175-188.

Virta, A. (2005). Citizen's alternative for participation in Finnish social studies textbooks for compulsory and senior secondary schools. In Ross, A. (Ed.), Teaching citizenship. London: CiCe, pp. 481-486.

Weber, M. (1971). Politics as a vocation. In Pizzorno, A. (Ed.) Political sociology. Middlesex: Penguine Books. 28-40.

Westheimer, J., \& Kahne, J. (2004). What kind of citizen? The politics of educating for democracy. American Educational Research Journal, 41(2), 1-30, Summer

Wheeler, W. K. (1967). Curriculum Process. London: Hodder and Stroughton.

Woolman, D. C. (2001). Educational reconstruction and post-colonial curriculum development: A comparative study of four African countries. International Education Journal, 2(5), 27-46.

Wronski, S. P. (1981). “Social studies around the world”. H. D. Mehlinger (Ed.), UNESCO Handbook for the Teaching of Social Studies (pp. 17-35). London: Croom Helm. 